\title{
Endoscopic surgery for intracranial cerebrospinal fluid cyst malformations
}

\section{Gangemi, M.D., F. Maiuri, M.D., G. Colella, M.D., and L. Sardo, M.D. Department of Neurosurgery, University "Federico II" of Naples, Naples, Italy}

Endoscopic surgery represents a new and very useful modality of treatment for intracranial cysts. The authors review the cases of 19 patients with intracranial malformative CSF cysts (seven intraventricular, six paraventricular, and six arachnoid) who underwent endoscopic fenestration by using a burr-hole approach. The various endoscopic approaches and techniques of fenestration, according to the type and location of the cyst, and the causes of unsuccessful outcome are critically discussed. The authors recommend endoscopic fenestration as the treatment of choice for patients with para- and intraventricular cysts, in whom the procedure may help to avoid the microsurgical approach and shunt placement in nearly all patients. In patients with arachnoid cysts, the endoscopic procedure, although associated with a lower rate of successful outcome, may be performed as the primary procedure in most cases because it is a minimally invasive procedure; the traditional surgical treatment may be performed without additional risk in which endoscopic surgery has failed.

Key Words * arachnoid cyst * cerebrospinal fluid cyst * choroid plexus cyst * endoscopy

Many types of cysts present in the cerebrospinal fluid (CSF) may occur intracranially, both in the brain parenchyma and in the ventricular and cisternal spaces, alone or in association with hydrocephalus.[21] These include porencephalic and ependymal cysts, those arising from a defect in the hemispheric cleavage and from the choroid plexus, and arachnoid cysts.

Until recently, symptomatic intracranial CSF cysts were treated by direct surgical fenestration, by excision via a craniotomy, or by placement of a peritoneal shunt. The development of endoscopic techniques has provided a new surgical modality with which to treat these cysts that obviates the need for further treatment in most cases.

In this paper we report a retrospective analysis of 19 patients with intraventricular, paraventricular, or arachnoid CSF cysts who underwent endoscopic surgery in our neurosurgical department. The different endoscopic techniques and the results according to the various types of cysts are discussed.

\section{CLINICAL MATERIAL AND METHODS}

A retrospective analysis of the endoscopic procedures performed for various intracranial disease entities 
between 1993 and 1998 was conducted in our neurosurgical department at the University "Federico II" of Naples. Of 80 operations (most of which were third ventriculostomies for hydrocephalus), 19 were performed in patients with CSF cystic malformations. We report on these 19 patients.

The case records, operative reports, and the pre- and postoperative computerized tomography (CT) and/or magnetic resonance (MR) imaging studies were analyzed.

After induction of a general anesthesic, the endoscopic procedure was performed in all cases by using a flexible endoscope (Model 83-1340, Codman; Johnson \& Johnson, Professional Inc., Raynham, MA), that consisted of a steerable fiberoptic imaging catheter measuring $4 \mathrm{~mm}$ in diameter. The surgical approach was performed in all cases via a burr hole. Fenestration of the cyst wall was performed using the coagulation (15 cases) or by gently pushing the tip of the probe (four cases).

All patients underwent CT scanning 3 to 7 days postoperatively and CT (four cases) or MR (15 cases) imaging 3 months or more thereafter. The actual follow-up period ranged from 12 to 64 months.

\section{RESULTS}

The 19 patients were divided into three groups according to location of the cyst. Seven patients (Group 1) harbored intraventricular, six (Group 2) paraventricular hemispheric, and six patients (Group 3) harbored arachnoid cysts (Table 1 and 2).

\section{Group 1}

Of the seven patients in whom intraventricular CSF cysts were present there were four males and three females; five were children between age 5 and 16 years-old and two were adults ( 27 and 24 years-old). In this group there was one cyst of the septum pellucidum, one of the velum interpositum, three of the choroid plexus, and two of the occipital horn of the lateral ventricle.

Preoperative clinical disturbances included intracranial hypertension in four cases, epileptic seizures in four, headache in two, hemiparesis in one, and slight mental retardation in one.

The neuroendoscopic procedure differed according to the type and location of the cyst. In one patient with a cyst of the septum pellucidum, fenestration was performed from the right frontal horn to the cyst via a right coronal burr-hole approach. In another case in which the cyst was located in the velum interpositum, fenestration from the right lateral ventricle to the cyst was performed, the cystic cavity was cannulated, and another fenestration was performed from the cavity to the left lateral ventricle. This technique of a two-window approach was performed to ensure free communication of the cyst with both lateral ventricles.

Of three patients with cysts located in the choroid plexus, one with mild-sized fluid collection (Case 3) underwent a procedure in which fenestration was performed from the homolateral ventricle to the cyst. In two other patients in whom very large cysts of the choroid plexus almost completely occupied one lateral ventricle (Cases 4 and 5; Fig. 1), the endoscope was first introduced in the contralateral normal, not enlarged, ventricle via an occipital burr hole, and the fenestration was performed from it to the cyst (Fig. 2); this approach has allowed us to identify easily the cyst wall protruding in the normal ventricle and to define the site of the fenestration. 


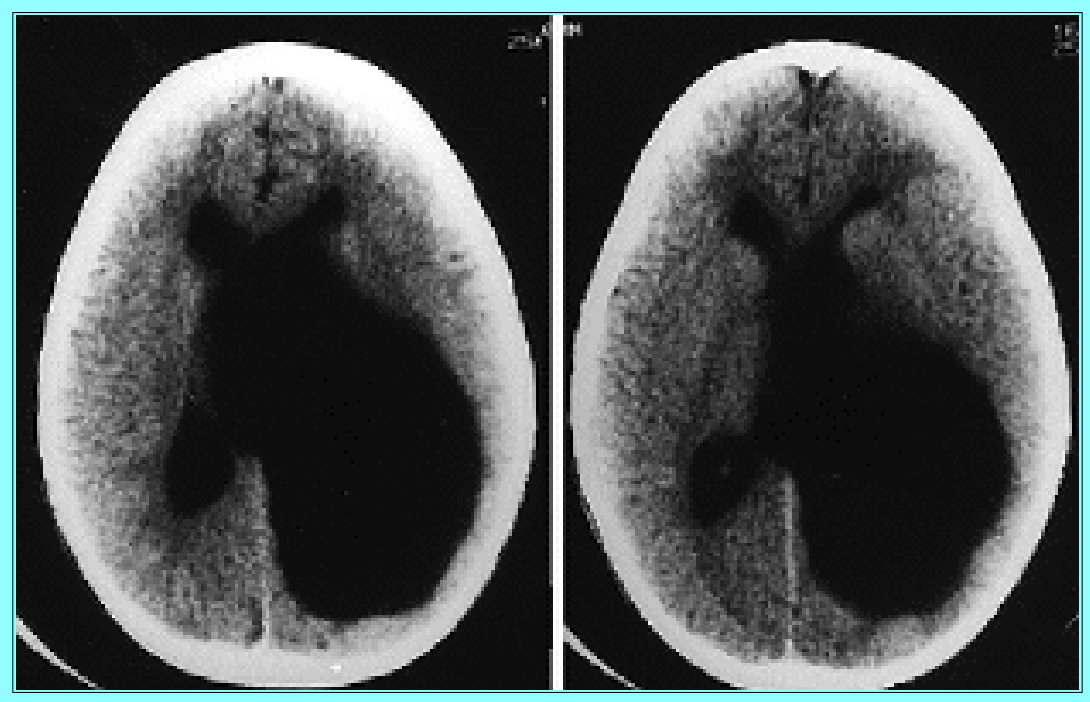

Fig. 1. Case 4. Computerized tomography studies. Left: Preoperative CT scan revealing a very large cyst of the choroid plexus on the left side, with marked mass effect on the right lateral ventricle. Right: A CT scan obtained 7 days after endoscopic fenestration of the cyst via a right occipital burr hole demonstrating cyst reduction, with good visualization of the right lateral ventricle and the anterior half of the left lateral ventricle.

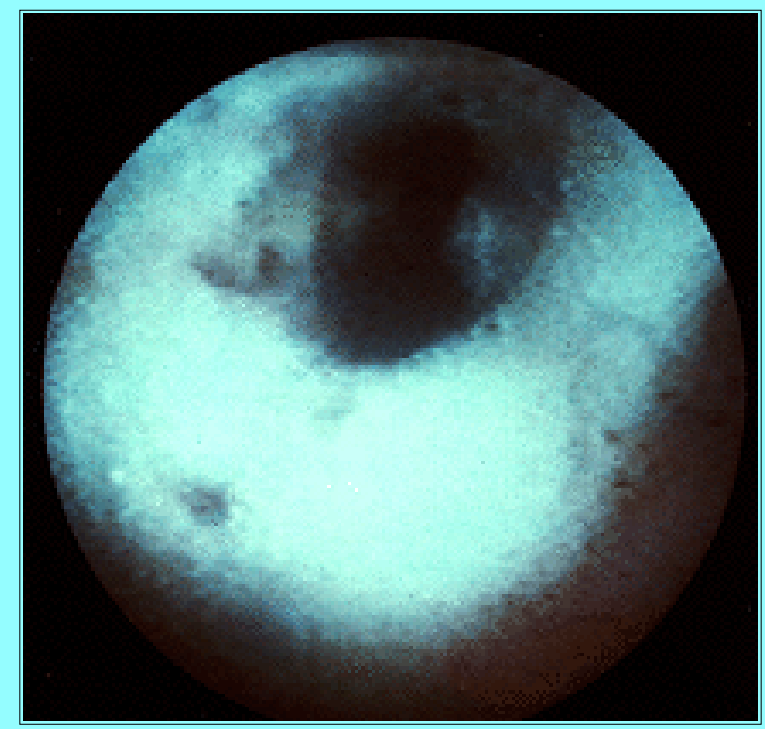

Fig. 2. Case 5. Intraoperative endoscopic view showing fenestration of a large choroid plexus cyst from the contralateral lateral ventricle.

In two patients in whom cysts were located in the occipital horn of the lateral ventricle (arachnoid and ependymal, respectively) fenestration was performed from the ventricle to the cyst via an occipital burr hole.

Postoperatively, resolution of intracranial hypertension (four cases) and headache (two cases) and decrease of frequency of the seizures (two cases) were observed. Variable and significant reduction of the cyst size was documented on CT and/or MR imaging studies in all patients. No further surgical treatment was necessary.

\section{Group 2}

Of the patients who harbored paraventricular intracranial CSF cysts (Table 1) there were two males and four females, who ranged in age from 6 months to 24 years-old (average 12 years). All harbored large cysts 
(4 to $6 \mathrm{~cm}$ ) of the parietal (three cases), parietooccipital (two cases) (Fig. 3), and frontoparietal region (one case). Five patients experienced epilepsy, two intracranial hypertension, and one hemiparesis.

\begin{tabular}{|c|c|c|c|c|c|c|}
\hline & DATA & ON PATIENTS WIT & $\begin{array}{r}\text { INTRAVENTRICI } \\
\text { BV E }\end{array}$ & $\begin{array}{l}\text { TABLE } 1 \\
\text { CSF AND PAR } \\
\text { OSCOPK SURGEF }\end{array}$ & ENTRICULAR CSF & STS TREATED \\
\hline $\begin{array}{l}\text { Case } \\
\text { No. }\end{array}$ & $\begin{array}{c}\text { Age (yrs), } \\
\text { Sex }\end{array}$ & $\begin{array}{c}\text { Localion } \\
\text { of Cyst }\end{array}$ & $\begin{array}{l}\text { Clirical } \\
\text { Features }\end{array}$ & $\begin{array}{l}\text { Fenestration } \\
\text { Tectnique }\end{array}$ & $\begin{array}{l}\text { Postop } \\
\text { Rad dogcal } \\
\text { Findings }\end{array}$ & $\begin{array}{l}\text { Outcome \& } \\
\text { Follow Up }\end{array}$ \\
\hline 1 & $13, M$ & $\begin{array}{l}\text { septum } \\
\text { pellucidum }\end{array}$ & $\begin{array}{l}\text { epilepsy, } \\
\text { headache }\end{array}$ & $\begin{array}{l}\text { rt frontal horn } \\
\text { to cyst }\end{array}$ & $\begin{array}{l}\text { reduction of } \\
\text { cyst }\end{array}$ & $\begin{array}{l}\text { headache resol ied, } \\
\text { seizure frequency } \\
\text { decreased }\end{array}$ \\
\hline 2 & $9, M$ & $\begin{array}{l}\text { velum inter- } \\
\text { positum }\end{array}$ & $\begin{array}{l}\mathrm{I} C \mathrm{H}, \text { mentil } \\
\text { retardation }\end{array}$ & $\begin{array}{l}\text { rt lat wentride } \\
\text { to cyst to It } \\
\text { lat ientride }\end{array}$ & $\begin{array}{l}\text { reduction of } \\
\text { cyst }\end{array}$ & $\mathrm{ICH}$ resolved \\
\hline 3 & $6, F$ & $\begin{array}{l}\text { rt choroid } \\
\text { plexus }\end{array}$ & $\mathrm{ICH}$, epile psy' & $\begin{array}{l}\text { rt lat wentride } \\
\text { to cyst }\end{array}$ & $\begin{array}{l}\text { reduction of } \\
\text { cyst, better } \\
\text { visualization } \\
\text { of rt lat ventricle }\end{array}$ & $\mathrm{ICH}$ resolved \\
\hline 4 & $5, F$ & $\begin{array}{l}\text { It choroid } \\
\text { plexus }\end{array}$ & ICH, epile psy' & $\begin{array}{l}\text { rt (contralat) } \\
\text { wentride to } \\
\text { cyst }\end{array}$ & $\begin{array}{l}\text { reduction of cyst, } \\
\text { visualization of } \\
\text { It lat 'en tride }\end{array}$ & $\begin{array}{l}\text { ICH resolved, } \\
\text { seizure frequency } \\
\text { decreased }\end{array}$ \\
\hline 5 & $16, M$ & $\begin{array}{l}\text { rt choroid } \\
\text { plexus }\end{array}$ & ICH, epile psy' & $\begin{array}{l}\text { It (contralat) } \\
\text { ventride to } \\
\text { cyst }\end{array}$ & $\begin{array}{l}\text { reduction of cyst, } \\
\text { visualization of } \\
\text { rtlat wentricte }\end{array}$ & $\mathrm{ICH}$ resolved \\
\hline 6 & & $\begin{array}{l}\text { It oocipital } \\
\text { horn }\end{array}$ & rt hemi paresis & $\begin{array}{l}\text { It lat uentride } \\
\text { to cyst }\end{array}$ & reduction of cyst & hemi paresis resol ved \\
\hline 7 & $24, F$ & $\begin{array}{l}\text { rt occi pital } \\
\text { horn }\end{array}$ & headache & $\begin{array}{l}\text { rt lat wentride } \\
\text { to cyst }\end{array}$ & reduction of cyst & headache resol ved \\
\hline 8 & $0.5, M$ & $\begin{array}{l}\text { It parietal } \\
(6 \mathrm{~cm})\end{array}$ & epilepsy & $\begin{array}{l}\text { cyst to lat wen- } \\
\text { tricle }\end{array}$ & reduction of cyst & $\begin{array}{l}\text { seizure frequency } \\
\text { decre ased }\end{array}$ \\
\hline 9 & $2, F$ & $\begin{array}{l}\text { rt parie tooc- } \\
\text { cipital (4 cm) }\end{array}$ & $\begin{array}{l}\text { epilepsy, men- } \\
\text { tal retarda- } \\
\text { tion }\end{array}$ & $\begin{array}{l}\text { cyst to lat ven- } \\
\text { tricle }\end{array}$ & $\begin{array}{l}\text { disappearance of } \\
\text { cyst }\end{array}$ & $\begin{array}{l}\text { seizure frequency } \\
\text { decreased }\end{array}$ \\
\hline 10 & $24, M$ & $\begin{array}{l}\text { rt parie tal } \\
(5 \mathrm{~cm})\end{array}$ & epilepsy & $\begin{array}{l}\text { cyst to lat wen- } \\
\text { tricle }\end{array}$ & reduction of cyst & seizures resolved \\
\hline 11 & $18, F$ & $\begin{array}{l}\text { It frontoparietal } \\
(5 \mathrm{~cm})\end{array}$ & $\begin{array}{l}\text { epilepsy, rt } \\
\text { hemi pare- } \\
\text { sis }\end{array}$ & $\begin{array}{l}\text { cyst to lat wen- } \\
\text { tricle }\end{array}$ & reduction of cyst & $\begin{array}{l}\text { hemi paresis resol ied, } \\
\text { seizure frequency } \\
\text { decreased }\end{array}$ \\
\hline 12 & $11, \mathrm{~F}$ & $\begin{array}{l}\text { rt parie tal } \\
(6 \mathrm{~cm})\end{array}$ & $\mathrm{ICH}$ & $\begin{array}{l}\text { cyst to lat wen- } \\
\text { tricle }\end{array}$ & reduction of cyst & $\mathrm{ICH}$ resolved \\
\hline 13 & $13, F$ & $\begin{array}{l}\text { It parietooci- } \\
\text { pital }(4,5 \mathrm{~cm})\end{array}$ & $\begin{array}{l}\text { epilepsy, } \\
\text { ICH }\end{array}$ & $\begin{array}{l}\text { cyst to lat wen- } \\
\text { tricle }\end{array}$ & $\begin{array}{l}\text { disappe arance } \\
\text { of cyst }\end{array}$ & $\begin{array}{l}\text { ICH resol wed, seizure } \\
\text { frequency de- } \\
\text { creased }\end{array}$ \\
\hline
\end{tabular}



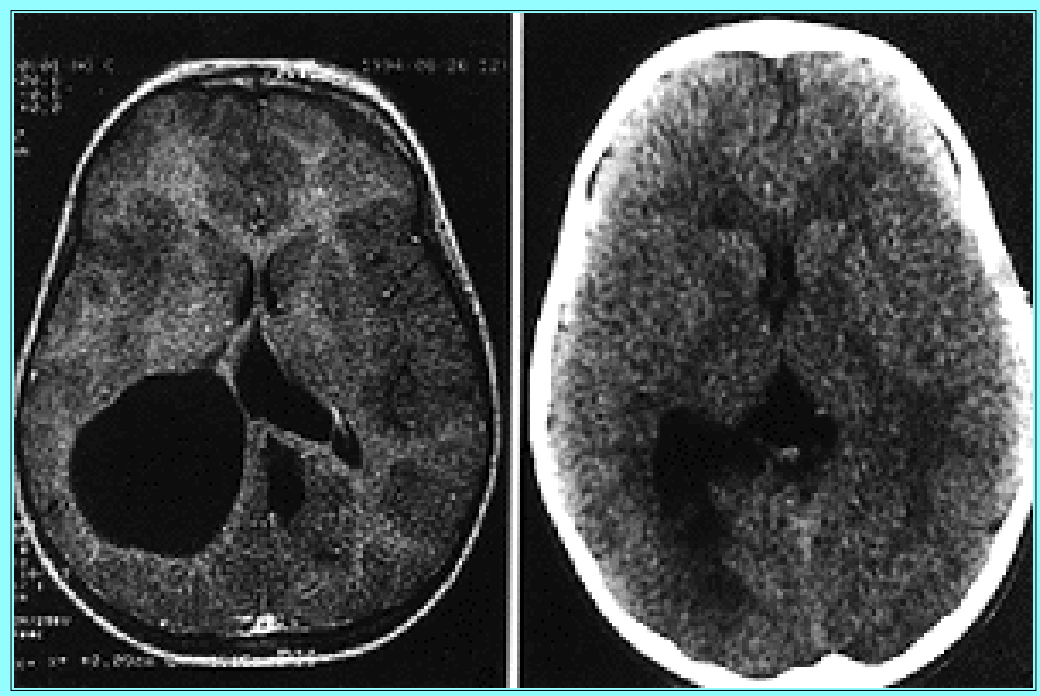

Fig. 3. Case 9. Left: Preoperative $T_{1}$-weighted axial MR image revealing a large right parietooccipital paraventricular CSF cyst compressing the right occipital horn. Right: Axial CT scan obtained after endoscopic ventricular fenestration demonstrating almost complete disappearance of the cyst.

All six patients first underwent cannulation of the cystic cavity; the wall of the cyst was explored and the limit between the cyst and the lateral ventricle was recognized as a protuberance of the cyst wall. After examining the consistency of the wall by using the electrode, fenestration was performed from the cyst to the lateral ventricle.

Postoperatively, in all six patients the cysts disappeared (three cases) or significantly decreased (three cases) in size, with no mass effect (Fig. 3 right). No further treatment was necessary.

\section{Group 3}

Of the six patients who harbored large arachnoid cysts of the suprasellar cistern (two cases), sylvian region (one case), quadrigeminal (two cases), and cerebellopontine angle cisterns (one case) (Table 2), all were symptomatic. 


\begin{tabular}{|c|c|c|c|c|c|c|c|}
\hline $\begin{array}{l}\text { Case } \\
\text { No. }\end{array}$ & $\begin{array}{l}\text { Age [ys] } \\
\text { Sex }\end{array}$ & $\begin{array}{l}\text { Location } \\
\text { of Cyst }\end{array}$ & $\begin{array}{l}\text { Clirical } \\
\text { Features }\end{array}$ & $\begin{array}{l}\text { Site of } \\
\text { Birr Hole }\end{array}$ & $\begin{array}{l}\text { Fenestration } \\
\text { Tectnique }\end{array}$ & $\begin{array}{l}\text { Postop } \\
\text { Rad dogcal } \\
\text { Findings }\end{array}$ & $\begin{array}{l}\text { Outcome \& } \\
\text { Follow Up }\end{array}$ \\
\hline 14 & $30, M$ & $\begin{array}{l}\text { suprasellar } \\
\text { cistem }\end{array}$ & $\begin{array}{l}\text { rhinoliquor- } \\
\text { rhea. }\end{array}$ & rt coronal & $\begin{array}{l}\text { rt lat wentride } \\
\text { to cyst }\end{array}$ & $\begin{array}{l}\text { slight reduction } \\
\text { of cyst }\end{array}$ & $\begin{array}{l}\text { rhinoliquorrhea } \\
\text { persists, } \\
\text { craniotom y }\end{array}$ \\
\hline 15 & $12, F$ & $\begin{array}{l}\text { suprasellar } \\
\text { cistem }\end{array}$ & $\mathrm{ICH}$ & rt coronal & $\begin{array}{l}\text { rt lat wentride to } \\
\text { cyst to prepon- } \\
\text { tine cistem }\end{array}$ & $\begin{array}{l}\text { reduction of cyst, } \\
\text { visualization of } \\
\text { 3rd wentricle, re- } \\
\text { mission of hydro- } \\
\text { cephalus }\end{array}$ & $\mathrm{ICH}$ resolved \\
\hline 16 & $40, M$ & $\begin{array}{l}\text { rt tem poro- } \\
\text { syluaan }\end{array}$ & seizures & rt pterional & $\begin{array}{l}\text { cyst to sylian } \\
\text { fissure }\end{array}$ & $\begin{array}{l}\text { reduction of cyst } \\
\& \text { mass effect }\end{array}$ & $\begin{array}{l}\text { seizure fre- } \\
\text { quency de- } \\
\text { creased }\end{array}$ \\
\hline 17 & $24, F$ & $\begin{array}{l}\text { quadrigem- } \\
\text { inal cistern }\end{array}$ & $\mathrm{ICH}$ & rt coronal & $\begin{array}{l}\text { 3rd wentricle to } \\
\text { cyst \& 3rd ien- } \\
\text { triculostomy }\end{array}$ & $\begin{array}{l}\text { reduction of hydro- } \\
\text { cephalus \& cyst } \\
\text { size }\end{array}$ & $\mathrm{ICH}$ resolved \\
\hline 18 & $8, F$ & $\begin{array}{l}\text { quadrigem- } \\
\text { inal cistern }\end{array}$ & $\mathrm{ICH}$ & rt coronal & $\begin{array}{l}\text { rt lat wentride to } \\
\text { cyst }\end{array}$ & reduction of cyst & $\mathrm{ICH}$ resolved \\
\hline 19 & 22, M & $\begin{array}{l}\text { It cerebello- } \\
\text { pontine angle } \\
\text { cistem }\end{array}$ & $\mathrm{ICH}$ & $\begin{array}{l}\text { It subocxipital } \\
\text { retromastoid }\end{array}$ & $\begin{array}{l}\text { cyst to prepon- } \\
\text { tine cistem }\end{array}$ & reduction of cyst & $\mathrm{ICH}$ resolved \\
\hline
\end{tabular}

The neuroendoscopic procedure differed according to the location of the cyst.

Two patients with large suprasellar arachnoid cysts and hydrocephalus (Fig. 4) underwent surgery via a right coronal burr hole; the frontal horn of the right lateral ventricle was first cannulated, and the cyst was found to protrude through the enlarged foramen of Monro (Fig. 5) Fenestration from the ventricle to the cyst was easily performed in both cases, and, the endoscope was then introduced into the cyst. However, the fenestration of the inferior wall of the cyst into the prepontine cistern was possible only in one case, whereas in the other it failed because the basal cisterns were completely obliterated.

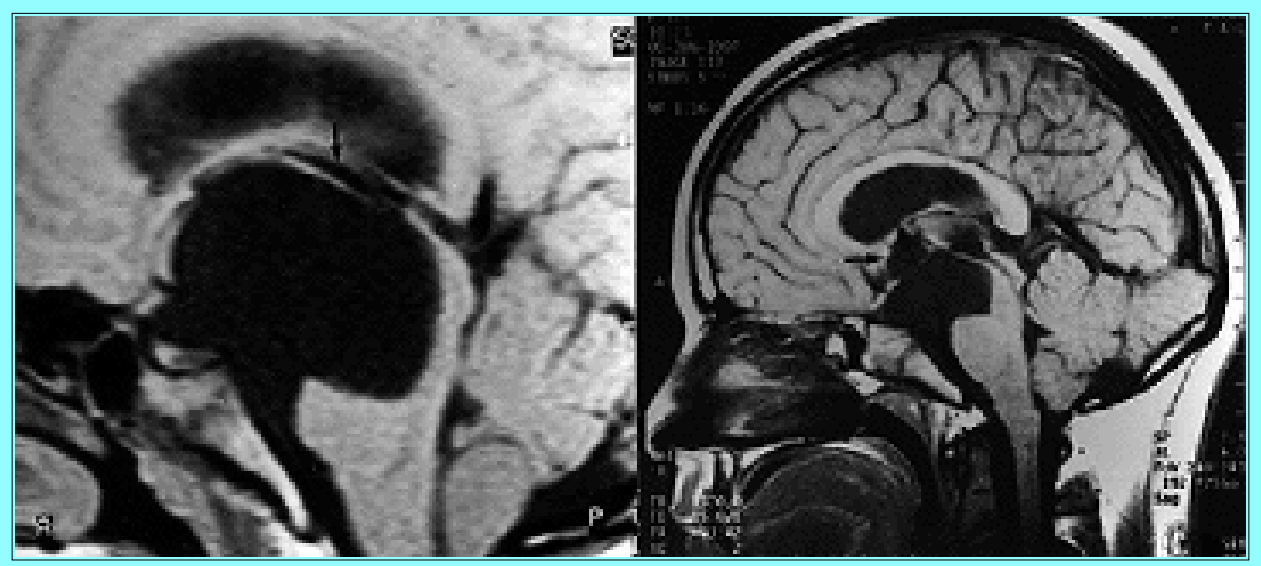

Fig. 4. Case 15. Left: Preoperative $T_{1}$-weighted sagittal $M R$ image revealing a large suprasellar arachnoid cyst with hydrocephalus; the third ventricle is compressed and not visible (arrow). Right: Post-endoscopic fenestration (lateral ventricle to cyst to prepontine cistern) $\mathrm{T}_{1}$-weighted sagittal MR image demonstrating significant decrease of the cyst size, disappearance of the hydrocephalus, visualization of the third ventricle (arrow). 


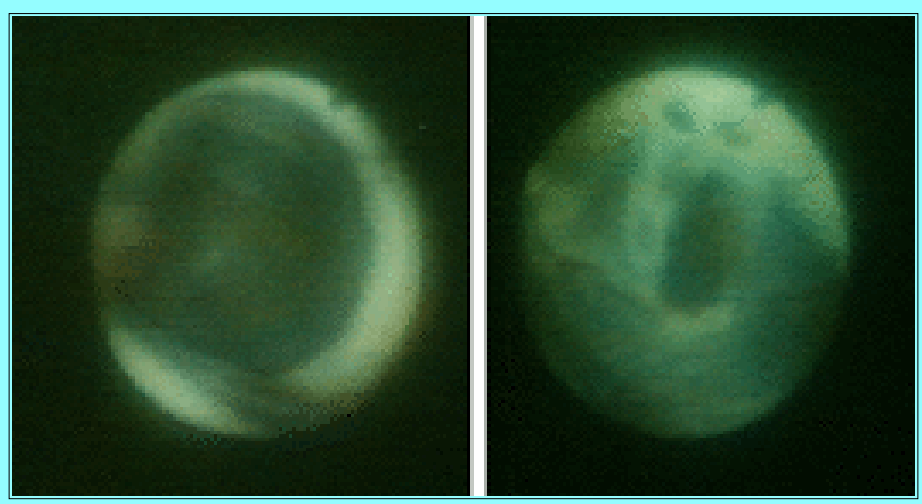

Fig. 5. Case 15. Intraoperative endoscopic views. Left: The cyst wall is well visualized from the lateral ventricle protruding through a very enlarged foramen of Monro. Right:

Post-endoscopic fenestration, the cyst wall is not visible, and the size of the foramen of Monro is significantly reduced.

In both patients who harbored large cysts of the quadrigeminal cistern there was an upward and lateral extension to the medial wall of the trigone and occipital horns of both lateral ventricles as well as to the posterior wall of the third ventricle. One was treated via a right coronal burr hole, with cannulation of the right lateral ventricle and fenestration from the trigone-occipital horn to the cyst. In the other case a right coronal approach allowed fenestration to be performed from the third ventricle to the cyst; this was followed by a third ventriculostomy.

The large arachnoid cyst of the sylvian region in one patient was approached through a pterional burr hole, and fenestration was performed from the cyst to the sylvian fissure. Finally, the large cyst of the left cerebellopontine angle cistern in one case was approached via a left suboccipital retromastoid burr hole, and fenestration was performed from the cyst to the prepontine cistern.

Postoperatively, in four patients intracranial hypertension resolved and in one patient partial control of seizures was achieved; in all these patients significant reduction of the cyst size and mass effect was obtained, with no further treatment required. In a patient with suprasellar cyst, the endoscopic fenestration from the lateral ventricle to the cyst without opening into the basal cisterns resulted only in slight decrease of the cyst size, whereas both hydrocephalus and rhinoliquorrhea persisted; thus, a craniotomy was performed to open the cyst widely to resolve the liquorrhea.

\section{DISCUSSION}

Intracranial CSF cysts of malformative origin represent a good indication for endoscopic surgery. Paraand intraventricular cysts may be easily fenestrated into the ventricular system; in these cases the endoscopic procedure usually allows the direct approach by craniotomy or the insertion of a shunt in most cases to be avoided.[2,4,13,15,20,25,27] On the other hand, endoscopic fenestration of arachnoid cysts is not as easy, and the indication for endoscopy is sometimes controversial; the usual lack of contiguity with the ventricular system and the obliteration of the subarachnoid spaces surrounding the cyst account for this.

The best candidates for endoscopic treatment are those with neurological signs and symptoms of space-occupying lesion and large CSF cysts with mass effect detected by MR or CT studies. Asymptomatic cysts with remarkable mass effect should be treated, particularly when they appear in children.

The endoscopic approaches and the techniques of fenestration vary according to the type and location of the cyst and are today debated. 
Paraventricular hemispheric CSF cysts may be easily treated by a well-established endoscopic technique. $[1,2,13,15]$ The burr hole must be created at the level of the more superficial point of the cyst and according to an easy and direct trajectory, as defined by MR imaging sequences. Fenestration from the cyst to the lateral ventricle is usually easy, because the cyst wall is generally thin. The exact site of the fenestration has been defined in all our cases during the endoscopic exploration as a prominence in the cyst wall caused by the underlying ventricle. Large and multiple fenestrations are necessary to avoid closure of the opening and recurrence of the cyst.

Midline intraventricular CSF cysts may derive from a defect in the hemispheric cleavage and may be located in the regions of the septum pellucidum, the cavum vergae, and the cavum velum interpositum. $[7,24,26]$ These rare cysts are discovered as an incidental radiological finding and are exceptionally symptomatic, due to obstruction of the foramina of Monro or to direct brain compression.[24,26]

The endoscopic treatment of midline intraventricular cysts consists of performing fenestration from the ventricular system to the cystic cavity. Cyst of the septum pellucidum may be approached via a right coronal burr hole and fenestrated from the right frontal horn to the cyst; in the patient in our Case 1 the endoscopic treatment resulted in a reduction of the cyst size and recanalization of the foramen of Monro.

Cysts of the cavum vergae and the velum interpositum may be approached via a parietal burr hole and fenestrated from the right trigone or occipital horn to the cystic cavity. The patient in Case 2 who harbored a cyst of the velum interpositum underwent a two-window endoscopic fenestration, from the right lateral ventricle to the cyst and then from the cystic cavity to the left lateral ventricle through the same right parietal burr hole. Although a one-window approach in which fenestration of one lateral ventricle is performed may be sufficient, we agree with Manwaring [16] that a two-window approach (right lateral ventricle to cyst to left lateral ventricle), allowing CSF to pass into both lateral ventricles and through the cyst freely, may improve the chances of long-term patency.[11]

Cysts of the choroid plexus are rare and develop near the foramen of Monro, thus producing monoventricular hydrocephalus. $[12,17]$ We think that the endoscopic approach to these cysts should be different, according to the cyst size and the residual lateral ventricle.

When the cyst is small or middle sized and occupies only a part of the ventricular cavity (as in Case 3), it may be reached through a ipsilateral occipital burr hole and treated by endoscopic fenestration from the ipsilateral enlarged ventricle to the cystic cavity. In our case the shrinkage of the cyst allowed us to recanalize the foramen of Monro and to obtain resolution of monoventricular hydrocephalus.

When the cyst is large and almost completely occupies the enlarged lateral ventricle, the approach through the ipsilateral ventricle is difficult or even impossible. In fact, the altered anatomy of the cyst and the enlarged lateral ventricle does not permit easy definition of the site of the cyst wall where the fenestration should be performed. Additionally, the reopening of the foramen of Monro is dangerous and not advisable. For these reasons, we advise that large choroid plexus cysts be approached through a contralateral occipital burr hole and that fenestration be performed from the contralateral, not enlarged, ventricle to the cyst, as demonstrated in Cases 4 and 5. In fact, the occipital horn of the contralateral and compressed lateral ventricle, although small, may be cannulated without difficulty; the septum pellucidum and the cyst wall are easily and immediately visualized to be protruding into the cannulated ventricle and may be fenestrated without difficulty. In both our cases this treatment resulted in reduction of the cyst size and recanalization of the foramen of Monro (Fig. 1 right). 
Various endoscopic approaches and trajectories may be utilized to treat arachnoid cysts according to the cyst location and size (Table 3).[3,6,8,9,14,18,22,23,28]

\begin{tabular}{|c|c|c|}
\hline \multicolumn{3}{|c|}{$\begin{array}{c}\text { TABLE } 3 \\
\text { ENDOSCOPIC TECHN QUES PERFORMED ACCORD NG TO THE LOCATION OF INTRACRANIAL } \\
\text { ARACHNOD CVSTS }\end{array}$} \\
\hline Cyst Location & Burr Hole Ste & Fenestration Techrique \\
\hline suprasellar region & rt coronal & $\begin{array}{l}\text { rt lateral wentricle to cyst to pre- } \\
\text { pontine cistern }\end{array}$ \\
\hline sylvian & pterional & cyst to syl wan cistern \\
\hline quadri & $\begin{array}{l}\text { paramedian suboc- } \\
\text { cipital } \\
\text { coronal } \\
\text { rt coronal }\end{array}$ & $\begin{array}{l}\text { supracerebellar cistem to cyst to } \\
\text { quadrigeminal cistern } \\
\text { trigone-occipital horn to cyst } \\
\text { 3rd wentricle to cyst }\end{array}$ \\
\hline train con wexity & $\begin{array}{l}\text { convexity at le vel } \\
\text { of the cyst }\end{array}$ & $\begin{array}{l}\text { cyst to subarachnoid space; cyst } \\
\text { to lat tentricle }\end{array}$ \\
\hline interemispheric fissure & parasagittal & $\begin{array}{l}\text { cyst to pericallosal cistern; cyst to } \\
\text { lat ientide }\end{array}$ \\
\hline cistema magna & $\begin{array}{l}\text { paramedian suboc- } \\
\text { cipital }\end{array}$ & cyst to cisterna magna \\
\hline $\begin{array}{l}\text { cerebellopontine angle } \\
\text { cistem }\end{array}$ & $\begin{array}{l}\text { subocipital retrosig- } \\
\text { moid }\end{array}$ & cyst to prepontine distern \\
\hline
\end{tabular}

Suprasellar arachnoid cysts may be easily reached via a right coronal burr hole approach, with cannulation of the right lateral ventricle and fenestration of the superior wall of the cyst through the enlarged foramen of Monro. This procedure, which was performed in Case 14, results in reducing the cyst size and partial refilling of the obliterated third ventricle. However, its use does not avoid the risk of recurrence, because the CSF continues to flow from the lateral ventricle into the cyst. For this reason, it is advisable, when possible, to perform a second fenestration at the level of the inferior wall of the cyst into the prepontine cistern, as in Case 15. This procedure of ventricle-cyst-cisternostomy, although less simple, allows restoration of the CSF flow from the cyst into the cisternal spaces and thus decreases the risk of recurrence.[5]

Our case in which the arachnoid cyst was located in the middle fossa was successfully treated by a pterional burr hole approach and fenestration from the cyst into the sylvian fissure. The sylvian vein and the middle cerebral artery are the main landmarks to identify the sylvian cistern. There is only a limited area for the fenestration, between the frontal and the temporal lobes and the sphenoid wing.[10] The internal carotid artery and its branches and the oculomotor nerve are the main structures at risk of damage during the procedure.

Arachnoid cysts of the quadrigeminal cistern are rather difficult to treat endoscopically because of their deep location and the surrounding vascular structures. Ruge, et al.,[23] have reported two such cases in which this endoscopic technique was performed; via a suboccipital paramedian burr hole approach they successfully performed endoscopic fenestration from the supracerebellar cistern to the cyst, removal of the posterior cyst wall, and fenestration of the anterior wall of the cyst into the ambient cistern. However, the risk of bleeding from the superior cerebellar brinding veins or deep incisural veins is associated with this approach; additionally, it may be more easily performed when the cyst extends downward and posteriorly over the cerebellum.[19]

We suggest two other different approaches to remove cysts of the quadrigeminal cistern. When the cyst is 
large enough and reaches a sufficient lateral extension, a coronal burr hole homolateral to the greater cyst extent, with cannulation of the lateral ventricle and fenestration from the trigone-occipital horn to the cyst, may be performed, as in our Case 18. When the cyst extends upward and anteriorly and displaces the posterior wall of the third ventricle with associated hydrocephalus, it may be treated via a right coronal burr hole approach in which fenestration is performed from the third ventricle to the cyst, as in our Case 17.

These two approaches may be performed only in large cysts of the quadrigeminal cistern that reach a sufficient anterolateral and upward extension. However, they present some advantages. First, the approach to the lateral and third ventricles through a coronal burr hole is rather easy and well standardized. Second, the fenestration of the cyst may be performed from a large cavity. Finally, there is no risk of damaging the deep veins of the incisural and quadrigeminal regions.

Arachnoid cysts of the brain convexity represent a less obvious indication for endoscopic surgery. In fact, fenestration from the cyst into the subarachnoid spaces is usually difficult to perform because the spaces are very compressed and almost completely obliterated. The initial CSF leak at the cyst opening is often sufficient to obtain moderate cyst detention and better visualization of the subarachnoid spaces. Large cortical cysts may be fenestrated into the ipsilateral lateral ventricle, when the brain cortex underlying the cyst is very thin and atrophic because of the chronic compression.

Cysts of the posterior fossa arachnoid region may be easily treated by performing a suboccipital approach. In cysts of the cerebellopontine angle (as in Case 19) a retromastoidal burr hole allows the cystic cavity to be easily cannulated; the space between the facial and trigeminal nerves is suitable for a fenestration between the cyst and the prepontine cistern. In midline cysts, a suboccipital paramedian burr hole can be used to reach directly the cyst and cerebellomedullar cistern and to perform a wide fenestration between them.

The postoperative radiological assessment of the successful endoscopic fenestration of intracranial malformative CSF cysts deserves consideration. Radiological findings that indirectly confirm the patency of the fenestration procedure include decrease of size of the cyst, reappearance of the previously compressed ipsilateral ventricle, and absence of mass effect on the midline structures. In contrast to the procedures in which shunts are placed, the complete disappearance of the cyst is infrequent (only two cases in our series); more often the reduction of size of the CSF cavity is only scarcely or moderately achieved, in spite of the good clinical outcome, mainly because the CSF pressure within the cyst decreases only slightly after endoscopic fenestration.

After the endoscopic treatment of cyst malformations, CSF flow through the fenestration is difficult to visualize on dynamic MR imaging studies, whereas this finding may be easily demonstrated after endoscopic third ventriculostomy.

The results of our series may be considered excellent, particularly for patients of Groups 1 and 2 who were all definitively cured after the endoscopic procedure, without necessity of a shunt placement or a direct approach to the cyst. Therefore, we consider the endoscopic fenestration the treatment of choice for patients who harbor intra- and paraventricular malformative CSF cysts. An extrathecal shunt or a direct approach to the cyst by craniotomy must be performed only in a small percentage of cases in which endoscopic fenestration cannot be performed or the cyst and the clinical symptoms recur after at least two endoscopic procedures.

The results of the endoscopic treatment in patients with arachnoid cysts seem to be less satisfactory (72\% 
of cases cured after the endoscopic procedure alone in our multicentric study [unpublished data]), as compared with those in patients who harbored intra- or paraventricular cysts.

The causes of unsuccessful outcome in cases of arachnoid cysts are manifold. The often reported difficulty of finding a suitable site in which to perform fenestration, due to obliteration of the surrounding subarachnoid spaces, is in our opinion the main surgical problem, particularly in cysts of the brain convexity. Large fenestrations in which wide openings are made in the cyst wall are necessary to restore the CSF flow into the subarachnoid spaces and to avoid cyst recurrence. On the other hand, the site suitable for the fenestration is often limited, and only relatively small fenestrations may be performed; in these instances, the fenestration may close up because there is no preferential CSF flowing through it. In addition, the fenestration of the cyst into the ventricular system alone may be insufficient if there is not fenestration also with the subarachnoid spaces, as it may occur for suprasellar cysts.

We did not observe intraoperative hemorrhagic complications in our series. On the other hand, others[10] have reported a more significant bleeding rate in cases of arachnoid cysts when compared with other neuroendoscopic procedures. Bleeding may originate from fragile arachnoidal blood vessels in the entry zone of the endoscope or near the site of the fenestration.

\section{CONCLUSIONS}

Endoscopic surgery plays a very important role in the treatment of intracranial malformative CSF cysts and may replace the microsurgical approach and shunting in most cases.

Different endoscopic approaches and trajectories of fenestration may be performed according to the cyst location and direction of growth. Preoperative MR imaging is necessary to define the most appropriate endoscopic trajectory in each case.

Although the number of patients in whom endoscopic surgery has been performed is small and their follow-up periods too short to compare with the results of standard approaches, the data obtained in our and other reported series of patients treated endoscopically seem to be good. Therefore, we recommend endoscopic fenestration as the treatment of choice for patients with para- and intraventricular CSF cysts. In cases of arachnoid cysts the endoscopic procedure may be performed in most cases according to the preoperative MR imaging findings because of its minimal invasivity. If the endoscopic technique fails, the microsurgical cyst fenestration or removal or shunt insertion may be performed without additional risk by enlarging the craniectomy.

\section{References}

1. Auer LM: Endoscopy of intraaxial lesions, in King WA, Frazee JG, De Salles AAF (eds): Endoscopy of the Central and Peripheral Nervous System. New York: Thieme, 1998

2. Caemaert J, Abdullah J, Calliauw L: Endoscopic diagnosis and treatment of para- and intra-ventricular cystic lesions. Acta Neurochir Suppl 61:69-75, 1994

3. Caemaert J, Abdullah J, Calliauw L, et al: Endoscopic treatment of suprasellar arachnoid cysts. Acta Neurochir 119:68-73, 1992

4. Cohen AR: Endoscopic ventricular surgery. Pediatr Neurosurg 19:127-134, 1993

5. Decq Ph, Yepes C, Anno Y, et al: L'endoscopie neurochirurgicale: indications diagnostiques et 
thérapeutiques. Neurochirurgie 40:313-321, 1994

6. Dhooge C, Govaert P, Martens F, et al: Transventricular endoscopic investigation and treatment of suprasellar arachnoid cysts. Neuropediatrics 23:245-247, 1992

7. Donauer E, Moringlane JR, Ostertag CB: Cavum vergae cyst as a cause of hydrocephalus, "almost forgotten"? Successful stereotactic treatment. Acta Neurochir 83:12-19, 1986

8. Eiras Ajuria J, Alberdi Vinas J: Traitement endoscopique des lésions intracraniennes. A propose de 8 cas. Neurochirurgie 37:278-283, 1991

9. Furuta S, Hatakeyama T, Nishizaki O, et al: Usefulness of neuroendoscopy in treating supracollicular arachnoid cysts--case report. Neurol Med Chir 38:107-109, 1998

10. Gaab MR, Schroeder HWS: Arachnoid cysts, in King WA, Frazee JG, De Salles AAF (eds):

Endoscopy of the Central and Peripheral Nervous System. New York: Thieme, 1998, pp 137-147

11. Gangemi M, Donati P, Maiuri F, et al: Cyst of the velum interpositum treated by endoscopic fenestration. Surg Neurol 47:134-137, 1997

12. Gangemi M, Maiuri F, Donati PA, et al: Endoscopic surgery for monoventricular hydrocephalus. Surg Neurol 51:1999 (In press)

13. Gangemi M, Maiuri F, Donati PA, et al: Endoscopic ventricular fenestration of intracranial fluid cysts. Minim Invasive Neurosurg 39:7-11, 1996

14. Grunert P, Perneczky A, Resh K: Endoscopic procedures through the foramen interventriculare of Monro under stereotactical conditions. Minim Invasive Neurosurg 37:2-8, 1994

15. Heilman CB, Cohen AR: Endoscopic ventricular fenestration using a "saline torch". J Neurosurg 74:224-229, 1991

16. Manwaring KH: Commentary on Gangemi M, et al: Cyst of the velum interpositum treated by endoscopic fenestration. Surg Neurol 47:137, 1997

17. Manwaring KH: Endoscopic ventricular fenestration, in Manwaring KH, Crone KR (eds):

Neuroendoscopy. New York: Mary Ann Liebert, 1992, Vol 1, pp 885-886

18. Merienne L, Leriche B, Roux FX, et al: Utilisation du laser Nd-YAG en endoscopie intracranienne. Expérience préliminaire en stéréotaxie. Neurochirurgie 38:245-247, 1992

19. Perneczky A: Commentary on Ruge JR, et al: Burr hole neuroendoscopic fenestration of quadrigeminal cistern arachnoid cyst: technical case report. Neurosurgery 38:837, 1996

20. Powers SK: Fenestration of intraventricular cysts using a flexible, steerable endoscope. Acta Neurochir Suppl 54:42-46, 1992

21. Raimondi AJ, Choux M, Di Rocco C (eds): Intracranial Cyst Lesions. New York: Springer-Verlag, 1993

22. Rampini P, Egidi M, Zavanone M, et al: Stereotactically guided endoscopy for the treatment of arachnoid cysts. Pediatr Neurosurg 29:102-104, 1998 
23. Ruge JR, Johnson RF, Bauer J: Burr hole neuroendoscopic fenestration of quadrigeminal cistern arachnoid cyst: technical case report. Neurosurgery 38:830-837, 1996

24. Sarwar M: The septum pellucidum: normal and abnormal. AJNR 10:989-1005, 1989

25. Yamamoto M, Oka K, Takasugi S, et al: Flexible neuroendoscopy for percutaneous treatment of intraventricular lesions in the absence of hydrocephalus. Minim Invasive Neurosurg 40:139-143, 1997

26. Yokota A: Cysts originating from a defect in the hemispheric cleavage (cavum septi pellucidi, cavum vergae, cavum veli interpositi), in Raimondi AJ, Choux M, Di Rocco C (eds): Intracranial Cyst Lesions. New York: Springer-Verlag, 1993, pp 87-99

27. Zamorano L, Chavantes C, Dujovny M, et al: Stereotactic endoscopic interventions in cystic and intraventricular brain lesions. Acta Neurochir Suppl 54:69-76, 1992

28. Zamorano L, Chavantes C, Moure F: Endoscopic stereotactic interventions in the treatment of brain lesions. Acta Neurochir Suppl 61:92-97, 1994

Manuscript received March 15, 1999.

Accepted in final form March 18, 1999.

Address reprint requests to: Michelangelo Gangemi, M.D., Dipartimento di Neurochirurgia, Università "Federico II," Via Pansini 5, 80131 Napoli, Italy.

\section{Table of Contents Return to Na//OC@}

